\title{
PENGARUH PENAMBAHAN LUMPUR AKTIF PADA BIOFILTER ANOKSIK-OKSIK DALAM MENURUNKAN KADAR AMONIA AIR LIMBAH RUMAH SAKIT
}

\author{
Ni Wayan Trisna Dewi ${ }^{* *}$, I Wayan Budiarsa Suyasa2), I Nyoman Rai ${ }^{3)}$ \\ 1) Program Studi Magister Ilmu Lingkungan Universitas Udayana Bali \\ ${ }^{2)}$ Fakultas Matematika dan Ilmu Pengetahuan Alam Universitas Udayana Bali \\ ${ }^{3)}$ Fakultas Pertanian Universitas Udayana Bali \\ *Email: il_trisna@yahoo.co.id
}

\section{ABSTRACT \\ THE EFFECT OF ACTIVATED SLUDGE ADDITION IN ANOXIC-OXIC BIOFILTERS IN REDUCING AMMONIA LEVELS OF HOSPITAL WASTE}

Development of the population and the increasing demand for health services has led to the increase in the number of hospitals, both government hospital and privet hospitals. The presence of ammonia as a result of protein decomposition can be toxic in the waters. The application of anoxicoxic biofilter system is an attempt to be able to reduce ammonia levels in hospital wastewater. In the process of anoxic-oxic biofilter, contact occurs between the gravel media and microorganism to form biofilms which can accelerate the degradation of organic matter and the nitrification process. This study aims to obtain the best activated sludge source in reducing ammonia levels of wastewater applied to the anoxic-oxic biofilter system applied. This research was contucted in two stages in which the first stage of active mud nursery was carried out from three sources, namely WWTP Wangaya Hospital Denpasar, WWTP of PTN Hospital Udayana University and WWTP of Bangli Hospital for six days. At this stage a Mixed Liquor Volatile Suspended Solid (MLVSS) value is measured which shows the growth rate of biomass in activated sludge. The second stage is applivation of avtivated sludge and control to the anoxic-oxic biofilter system to reduce ammonia levels in hospital wastewater for five days of processing. This study use a randomized block design with four treatments and three replication. The results showed that the best activated sludge was obtained through nursery from WWTP of Wangaya Denpasar Hospital which was shown by the highest biomass growth (MLVSS Value) of $2433.3 \mathrm{mg} / \mathrm{L}$ and the highest reduction in ammonia reached a final level of $0.53 \mathrm{mg} / \mathrm{L}$. The levels of effectiveness of the process of decreasing ammonia levels by $94.70 \%$ and has been able to pass the specified quality standard effectiveness percentage (90\%) for five days of processing. The value of this effectiveness is the highest compared to the controls and other activated sludge treatment.

Keywords: Biofilter Anoxic-Oxic, Ammonia, Activated Sludge.

\section{PENDAHULUAN}

Perkembangan penduduk yang sangat pesat dan meninngkatnya tuntutan peyanan kesehatan semakin mendorong peningkatan laju bertambah ya rumah sakit, baik rumah sakit pemerintah maupun swasta. Meningkatnya jumlah rumah sakit yang beroperasi menyebabkan potensi pencemaran lingkungan yang diakibatkan dari kegiatan rumah sakit akan semakin meningkat. Air limbah yang berasal dari kegiatan rumah sakit merupakan salah satu sumber pencemar air yang sangat potensial. Hal ini disebabkan karena air limbah rumah sakit mengandung senyawa organik 
dengan konsentrasi yang cukup tinggi. Oleh karena itu diperlukan adanya upaya pengolahan limbah sesuai dengan karakter limbah itu sendiri sehingga tidak mengganggu struktur lingkungan dan memenuhi standar baku mutu sesuai dengan peruntukannya.

Pengolahan pada Instalansi Pengolahan Air Limbah (IPAL) merupakan upaya untuk meminimalkan kadar pencemar yang terkandung dalam limbah cair sehingga dapat memenuhi standar Baku Mutu dan layak untuk dibuang ke lingkungan maupun dimanfaatkan kembali. Rumah Sakit Umum Daerah (RSUD) Wangaya Denpasar merupakan rumah sakit denga tipe B-non pendidikan telah melakukan pengolahan limbah cair denga menggunakan satu unit Instalansi Pengolahan Air Limbah (IPAL). Rumah Sakit PTN Universitas Udayana merupakan sebuah rumah sakit baru yang dimiliki Universitas Udayana dan telah menyediakan Instalansi Pemgolahan Air Limbah yang menampung pembuangan limbah dari instalansi-instalansi pelayanan di rumah sakit. Di Rumah Sakit Umum Daerah (RSUD) Bangli juga telah dilengkapi sarana pengolahan limbah seperti IPAL untuk mengolah limbah cairnya.

Limbah cair mengandung bibit penyakit yang dapat menimulkan penyakit bawaan air. Limbah cair yang tidak dikelola dengan baik juga dapat menjadi sarang vektor penyakit. Vektor penyakit tersebut dapat mem bawa mikroorganisme patogen penyebab penyakit seperti kolera, filarial, penyakit cacing dan tifoid. Penyakit yang ditimbulkan dari limbah berbahaya dapat bersifat akut dan kronis. Salah satu limbah cair yang dihasilkan oleh rumah sakit adalah amonia. Keberadaan amonia sebagai hasil dekomposisi protein dapat bersifat toksik dalam perairan. Kadar amonia yang masih tinggi berkontribusi terhadap terjadinya proses eutrofikasi, sehingga menghalangi penetrasi sinar matahari ke dalam perairan dan mengganggu proses fotosintesis. Kondisi tersebut dapat menyebabkan penurunan kadar oksigen terlarut pada air, mengganggu proses respirasi biota bahkan menyebabkan kematian (Widiyanto, 2016).
Salah satu cara untuk mendegradasi air limbah rumah sakit yang ramah lingkungan adalah dengan cara biologis dengan sistem biofilter anoksik-oksik dengan penambahan media kerikil. Pada biofilter anoksik-oksik, air limbah yang diolah akan mengalami kontak dengan mikroorganisme tersuspensi dalam air maupun yang menempel pada permukaan media (biofilm). Hal tersebut akan mempercepat proses degradasi bahan organik bahan organik dan proses nitrifikasi sehingga efisiensi penghilangan amonia menjadi lebih besar. Dalam pengolahan sistem biofilter anoksik-oksik ini perlu diperhatikan faktorfaktor yang mempengaruhi proses diantaranya waktu pengolahan, sumber mikroorganisme, kadar oksigen terlarut dan kondisi $\mathrm{pH}$ (derajat keasaman).

Proses lumpur aktif dalam pengolahan air limbah dilakukan dengan biakan tersuspensi (Ningtyas, 2015). Metode lumpur aktif dilakukan untuk menghilangkan BOD, nitrifikasi, dan denitrifikasi (Anderson, 2014). Pada proses nitrifikasi, terjadi oksidasi amonia menjadi nitrit dan nitrat oleh bakteri. Sedangkan proses denitrifikasi, nitrit dan nitrat terkonversi menjadi gas nitrogen. Penelitian ini bertujuan untuk memperoleh lumpur aktif yang mampu menurunkan kadar amonia air limbah yang diterapkan pada sistem biofilter anoksikoksik serta untuk menentukan tingkat efektivitas penurunan kadar amonia pada air limbah dengan penerapan lumpur aktif pada sistem biofilter anoksik-oksik.

\section{METODOLOGI}

\subsection{Lokasi dan Waktu Penelitian}

Sumber sedimen lumpur yang akan dibibit (seeding) menjadi lumpur aktif diambil dari tiga lokasi berbeda yaitu IPAL Rumah Sakit Umum Daerah (RSUD) Wangaya Jalan Kartini No. 13 Denpasar, IPAL Rumah Sakit Perguruan Tinggi Negeri (RS PTN) Universitas Udayana Jalan Rumah Sakit Unud, Jimbaran, Kuta Selatan, Badung dan IPAL Rumah Sakit Umum Daerah (RSUD) Bangli Jalan Brigjen Ngurah Rai No. 99x Bangli. Waktu penelitian 
dilakukan pada Bulan Oktober sampai Desember 2018.

\subsection{Prosedur Penelitian}

\subsubsection{Pembibitan Lumpur Aktif}

Dari masing-masing lokasi penelitian dilakukan pembibitan (seeding) dengan cara mengambil 10 gram sedimen lumpur kemudian tiap sedimn dimasukkan ke dalam toples $5 \mathrm{~L}$. Selanjutnya lumpur ditambahkan nutrient hara (pupuk urea 5 gram, pupuk KCl 2,5 gram, pupuk TSP 2,5 gram, larutan glukosa 10 gram, dan serbuk $\mathrm{NH}_{4} \mathrm{Cl} 5$ gram) kemudian diencerkan dengan aquadest sampai volume 2 L. Kemudian campuran diaduk sampai homogen dan diberi aerasi.

Selama enam hari pertumbuhan isolat bakteri diamati dengan mengukur nilai MLVSS (Mixed Liquour Volatile Suspended Solid) hingga mencapai nilai 2000 mg/L (Herlambang, 2017). Lumpur atif yang telah jadi diaplikasikan untuk mengolah air limbah buatan (artificial) dengan kadar amonia sebesar 10 ppm melalui sistem biofilter anoksik-oksik dengan media kerikil.

\subsubsection{Penentuan Sumber Lumpur Aktif Terbaik}

Dalam penentuan sumber lumpur aktif terbaik disediakan 4 reaktor biofilter anoksikoksik dengan ketentuan:

Reaktor 1: $40 \%$ (4 L) lumpur aktif dari IPAL RSUD Wangaya Denpasar (S1).

Reaktor 2 : 40\% (4 L) lumpur aktif dari IPAL RS PTN Universitas Udayana (S2).

Reaktor 3 : $40 \%$ (4 L) lumpur aktif dari IPAL RSUD Bangli (S3).
Masing-masing reaktor dialirkan 60\% (6 L) air limbah artificial.

Reaktor 4 : 100\% air limbah sebagai kontrol.

Air limbah dibiarkan selama satu hari untuk proses stabilisasi dan pembentukan lapsian biofilm. Selanjutnya air limbah pada semua reaktor pengolahan diberikan waktu tinggal pengolahan selama lima hari dan dilakukan analisis kadar amonia pada air limbah. Dari pengukuran kadar amonia, ditentukan sumber lumpur aktif terbaik yang mampu menurunkan kadar amonia serta perhitungan mengenai tingkat efektivitas sistem biofilter anoksik-oksik dalam menurunkan kadar amonia.

\subsection{Analisis Data}

Analisis data dilakukan dengan dua cara yaitu membandingkan hasil analisis yang diperoleh dengan Baku Mutu Air Limbah Rumah Sakit Berdasarkan Peraturan Gubernur Bali No. 8 Tahun 2016 dan Analisis Kovarians (Anakova) untuk menentukan pengaruh penggunaan sumber lumpur aktif selama waktu pengolahan terhadap penurunan kadar amonia dalam sistem biofilter anoksik-oksik.

\section{HASIL DAN PEMBAHASAN}

\subsection{Pembibitan Lumpur Aktif}

Hasil analisis kadar Mixed Liqour Volatile Suspended Solid (MLVSS) proses pembibitan lumpur aktif selama enam hari dari tiga lokasi yang ditentukan disajikan pada Gambar 1. 


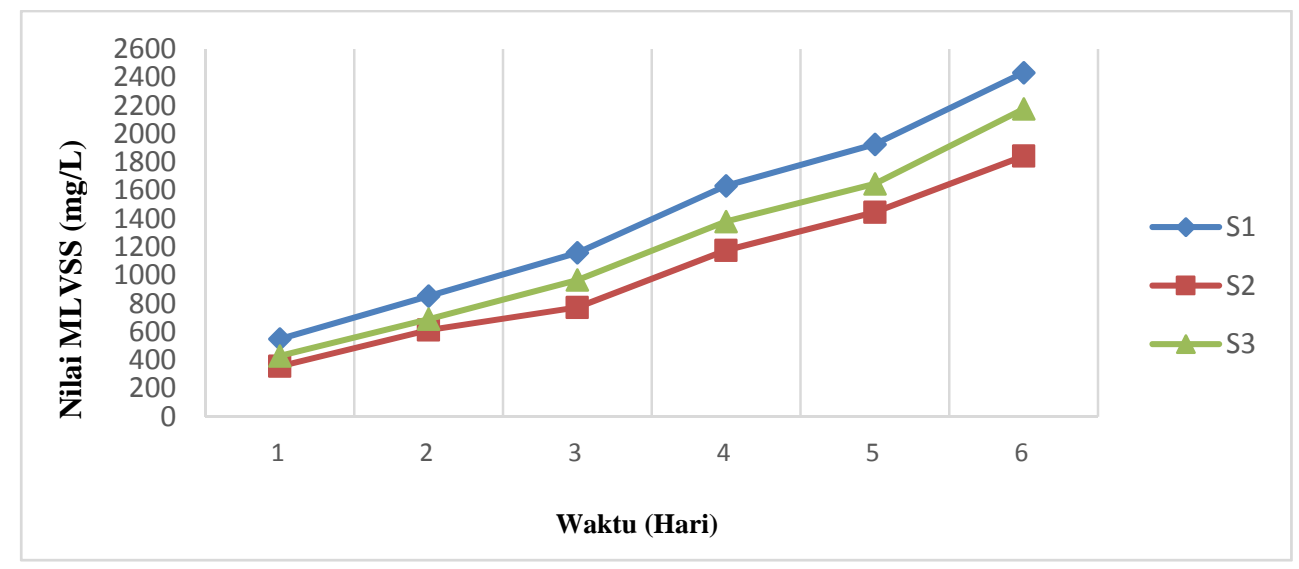

Gambar 1.

Rata-Rata Nilai MLVSS Dari Tiga Sumber Lumpur

Selama Proses Pembibitan Dengan Waktu Pengolahan Selama Enam Hari

Keterangan:

S1 = Lumpur dari IPAL RSUD Wangaya Denpasar

S2 = Lumpur dari IPAL RS PTN Universitas Udayana

S3 = Lumpur dari IPAL RSUD Bangli.

Berdasarkan Gambar 1. Terlihat bahwa terjadi peningkatan nilai MLVSS pada ketiga sumber lumpur yang digunakan dalam proses pembibitan. Pertumbuhan biomassa mikroorganisme dalam lumpur aktif selama proses pembibitan sangat didukung adanya nutrien (makanan) yang diberikan serta pemberian oksigen (proses aerasi) yang menunjang ketersediaan oksigen terlarut dalam lumpu aktif. Sumber lumpur dari IPAL RSUD Wangaya Denpasar (S1) yang digunaka dalam pembibitan memiliki tingkat pertumbuhan biomassa dengan nilai MLVSS yang paling tinggi. Kondisi tersebut dapat disebabkan cukup banyaknya variasi jenis mikroorganisme yang berasal dari sedimen lumpur yang digunakan. IPAL RSUD Wangaya Denpasar mengolah air limbah dengan kadar bahan organik yang cukup tinggi. Kandungan bahan organik tinggi pada perairan tercemar akan tercipta suasana yang sesuai bagi mikroorganisme untuk menggunakan bahan organik tersebut dalam proses metabolismenya (Turista, 2017). Makin tinggi aktivitas mikroorganisme dalam menguraikan bahan organik semakin tinggi pula biomassa yang dihasilkan. Peningkatan biomassa ini menyatakan nilai MLVSS yang diukur dan jumlah bahan organik yang telah didegradasi oleh mikroorganisme (Ni'weh, 2014). Diduga beberapa jenis bakteri yang mampu tumbuh pada sistem pengolahan anoksik-oksik (kolam aerasi) yaitu dari Genus Bacillus, Pseudomonas, Vibrio, Escherichia coli, sedangkan jenis alga yang mampu tumbuh seperti dari Genus Euglena serta Spirogyra. Keberadaan bakteri dan alga dalam perairan tercemar bahan organik menyebabkan terjadinya simbiosis. Bakteri berperan sebagai pengurai sedangkan alga berfungsi sebagai konsumen sekaligus berfungsi sebagai produsen yaitu penghasil oksigen.

Berdasarkan analisis kovarians (Anakova) terhadap kadar MLVSS diketahui bahwa ketiga lumpur yang digunakan dalam proses pembibitan (seeding) berpengaruh sangat nyata terhadap nilai MLVSS yang diukur. Sumber varians (keragaman) lainnya menyebabkan pengaruh yang sangat nyata terhadap kadar MLVSS adalah waktu pengolahan yaitu selama enam hari. Hasil analisis juga menunjukkan adanya interaksi nyata antara jenis lumpur yang digunakan dengan waktu pengolahan yang diberikan selama proses pembibitan (seeding). 


\subsection{Penentuan Sumber Lumpur Aktif Terbaik}

Sebelum memasuki proses pengolahan dalam reaktor biofilter, air limbah mengalami proses stabilisasi terlebih dahulu yang bertujuan untuk menghomogenkan kandungan bahan organik dalam limbah dan menstabil kondisi air limbah sehingga siap digunakan untuk proses pengolahan selantunya. Proses stabilisasi air limbah memberikan kontribusi terhadap penurunan kadar amonia walaupun dalam jumlah yang sedikit. Selama proses stabilisasi mikroorganisme mulai membentuk lapisan biofilm pada media kerikil dan mikroorganisme menjalankan aktivitasnya menguraikan bahan organik maupun amonia dalam air limbah sehingga setelah proses stabilisasi selesai terjadi penurunan kadar amonia yang relative kecil. Penurunan kadar amonia yang relative kecil disebabkan karena belum adanya supply oksigen selama proses stabilisasi sehingga aktivitas mikroorganisme masih terbatas.

Pada perlakuan lumpur aktif S1 terjadi penurunan kadar amonia dari awal sebesar 10
mg/L menjadi $0,53 \mathrm{mg} / \mathrm{L}$, untuk aplikasi lumpur aktif S2 terjadi penurunan kadar amonia dari $10 \mathrm{mg} / \mathrm{L}$ menjadi 1,63 mg/L. Sedangkan pada aplikasi lumpur aktif S3 menyebabkan penurunan kadar amonia dari $10 \mathrm{mg} / \mathrm{L}$ menjadi 0,86 mg/L. Jika dibandingkan dengan kontrol yaitu pengolahan air limbah tanpa menggunakan lumpur aktif, penurunan kadar amonia dengan perlakuan (penambahan lumpur dari tiga sumber) memberikan hasil yang lebih baik. Penurunan kadar amonia disebabkan oleh adanya aktivitas mikroorganisme nitrifikasi yang dapat menguraikan amonia dalam air limbah menjadi nitrit atau nitrat melalui suatu reaksi nitrifikasi. Pada pembibitan lumpur aktif penambahan nutrien yang mengandung amonia juga merangsang pertumbuhan mikroorganisme perombak amonia (mikroorganisme nitrifikasi) sehingga proses pengolahan air limbah berjalan maksimal.

Hasil analisis kadar amonia pada pengolahan air limbah artificial dengan menggunakan tiga sumber lumpur aktif, tercantum pada Gambar 2.

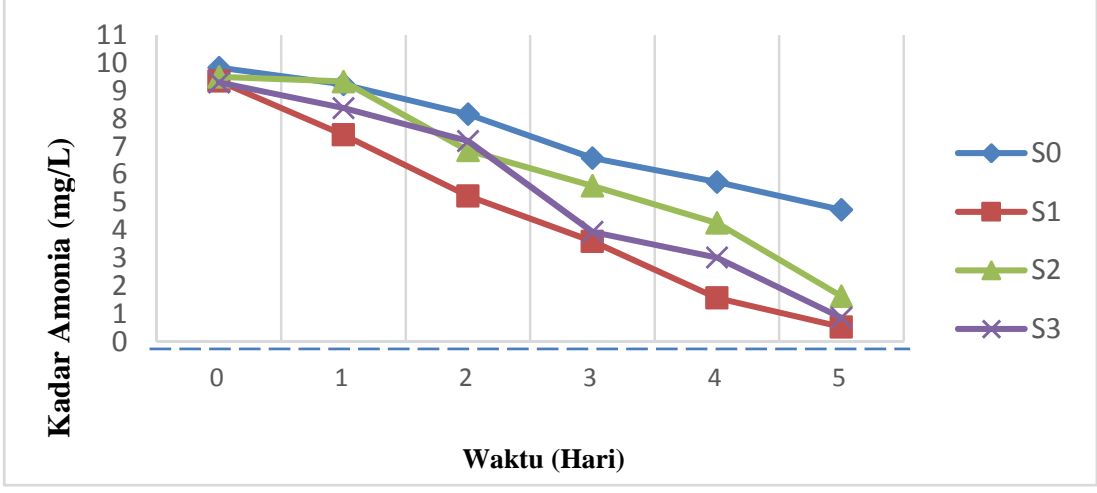

Gambar 2.

Penurunan Kadar Amonia Pada Masing-Masing Perlakuan Dan Kontrol Selama 5 Hari Pengolahan

Keterangan:

S0 $=$ Kontrol (tanpa penambahan lumpur aktif)

S1 = Lumpur dari IPAL RSUD Wangaya Denpasar

$\mathrm{S} 2$ = Lumpur dari IPAL RS PTN Universitas Udayana

S3 = Lumpur dari IPAL RSUD Bangli

- - - = Baku Mutu Amonia Pada Air Limbah

Rumah Sakit Berdasarkan Peraturan Gubernur Bali No. 16 Tahun 2016.
Berdasarkan analisis kadar amonia terhadap tiga jenis lumpur aktif tersebut terlihat aplikasi lumpur aktif S1 memberikan hasil pengolahan yang paling baik dengan penurunan kadar amonia paling besar jika dibandingkan dengan aplikasi kedua jenis lumpur lainnya (S2 dan S3) serta kontrol (S0). Penurunan kadar 
amonia ini disebabkan oleh adanya variasi dan jumlah mikroorganisme yang lebih tinggi sehingga laju aktivitas penguraian amonia dalam air limbah akan lebih tinggi. Berdasarkan hasil Analisis Kovarians (Anakova) terhadap kadar amonia diketahui bahwa perlakuan yang diberikan dalam pengolahan sistem biofilter anoksik-oksik (penggunaan tiga jenis lumpur aktif dan kontrol) memberikan pengaruh yang sangat nyata terhadap penurunan kadar amonia air limbah. Sumber varians lainnya menyebabkan pengaruh yang sangat nyata terhadap penurunan kadar amonia adalah waktu pengolahan yaitu selama lima hari. Hasil analisis juga menunjukkan adanya interaksi nyata antara jenis lumpur yang digunakan dengan waktu pengolahan yang diberikan selama proses pengolahan air limbah dengan sistem biofilter anoksik-oksik.

\subsection{Efektivitas Sistem Biofilter Anoksik- Oksik Terhadap Penurunan Kadar Amonia}

Tingkat efektivitas terhadap penurunan kadar amonia ditinjau dari dua aspek yaitu efektivitas pada setiap proses pengolahan air limbah (Tabel 1) dan efektivitas terhadap baku mutu yang ditetapkan (Tabel 2).

Tabel 1. Efektivitas Proses Pengolahan Air Limbah Dalam Menurunkan Kadar Amonia Dengan Sistem Biofilter Anoksik-Oksik

\begin{tabular}{|c|c|c|c|c|c|}
\hline \multirow[t]{2}{*}{ NO } & \multirow[t]{2}{*}{ Perlakuan } & \multicolumn{2}{|c|}{$\begin{array}{c}\text { Nilai Amonia } \\
\text { Rata-rata }(\mathrm{mg} / \mathrm{L})\end{array}$} & \multirow{2}{*}{$\begin{array}{l}\text { Persentase } \\
\text { Penurunan } \\
\text { Amonia (\%) }\end{array}$} & \multirow{2}{*}{$\begin{array}{c}\text { Efektivitas Proses } \\
\text { Pengolahan }\end{array}$} \\
\hline & & $\mathrm{T}_{0}$ & $T_{5}$ & & \\
\hline 1 & S0 & 10 & 4,73 & 52,70 & Efektif* \\
\hline 2 & S1 & 10 & 0,53 & 94,70 & Efektif* \\
\hline 3 & S2 & 10 & 1,63 & 83,70 & Efektif* \\
\hline 4 & S3 & 10 & 0,86 & 91,40 & Efektif* \\
\hline
\end{tabular}

Tabel 2. Efektivitas Baku Mutu Dalam Menurunkan Kadar Amonia Air Limbah Dengan Sistem Biofilter Anoksik-Oksik

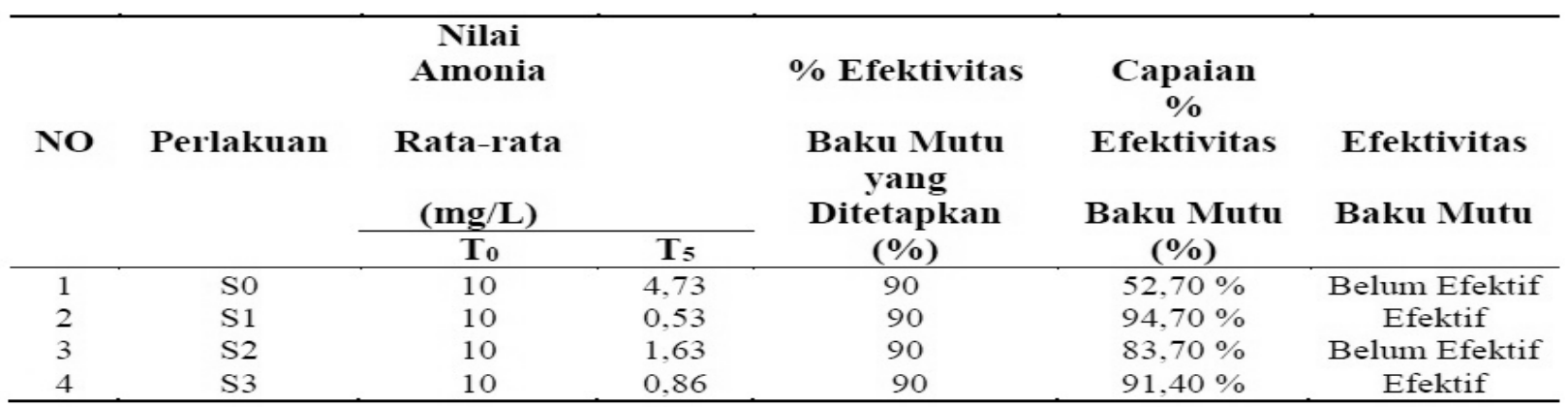

Keterangan:

$\mathrm{T}_{0}=$ Kadar Amonia awal pada air limbah artificial

$\mathrm{T}_{5}=$ Kadar amonia setelah pengolahan 5 hari 


\subsubsection{Efektivitas Sistem Biofilter Anoksik- Oksik Terhadap Aplikasi Lumpur Aktif S1}

Dari Gambar 3 terlihat bahwa sistem biofilter anoksik-oksik dengan aplikasi lumpur aktif S1 mampu menurunkan kadar amonia air limbah dibawah baku mutu yang ditetapkan yaitu $1 \mathrm{mg} / \mathrm{L}$. Pada aplikasi lumpur aktif S1 selang waktu lima hari menyebabkan terjadi penurunan kadar amonia dari $10 \mathrm{mg} / \mathrm{L}$ menjadi 0,53 mg/L. Tingginya penurunan kadar amonia pada aplikasi lumpur aktif S1 dapat disebabkan karena tingginya biomassa (yang dilihat dari nilai MLVSS) dan keberagaman jenis mikroorganisme yang mampu hidup dalam lumpur aktif S1. Kondisi yang kaya organik menyebabkan mikroorganisme mampu berkembangbiak pada sedimen lumpur IPAL RSUD Wangaya Denpasar. Keberadaan mikroorganisme akan menunjang proses penguraian bahan organik yang ada dalam air limbah.

Berdasarkan Tabel 1 diketahui tingkat efektivitas proses pengolahan air limbah dengan aplikasi lumpur aktif S1 menunjukkan persentase penurunan kadar amonia selama lima hari pengolahan sebesar 94,70\% sedangkan aspek efektivitas yang ditinjau dari segi baku mutu menunjukkan aplikasi lumpur aktif S1 mampu menurunkan kadar amonia air limbah selama selang waktu lima hari pengolahan melewati persentase efektivitas baku mutu yang ditentukan yaitu sebesar 90\% (Tabel 2). Dari kedua aspek yang diamati memberikan hasil bahwa sistem biofilter anoksik-oksik dengan aplikasi lumpur aktif S1efektif digunakan untuk menurunkan kadar amonia air limbah.

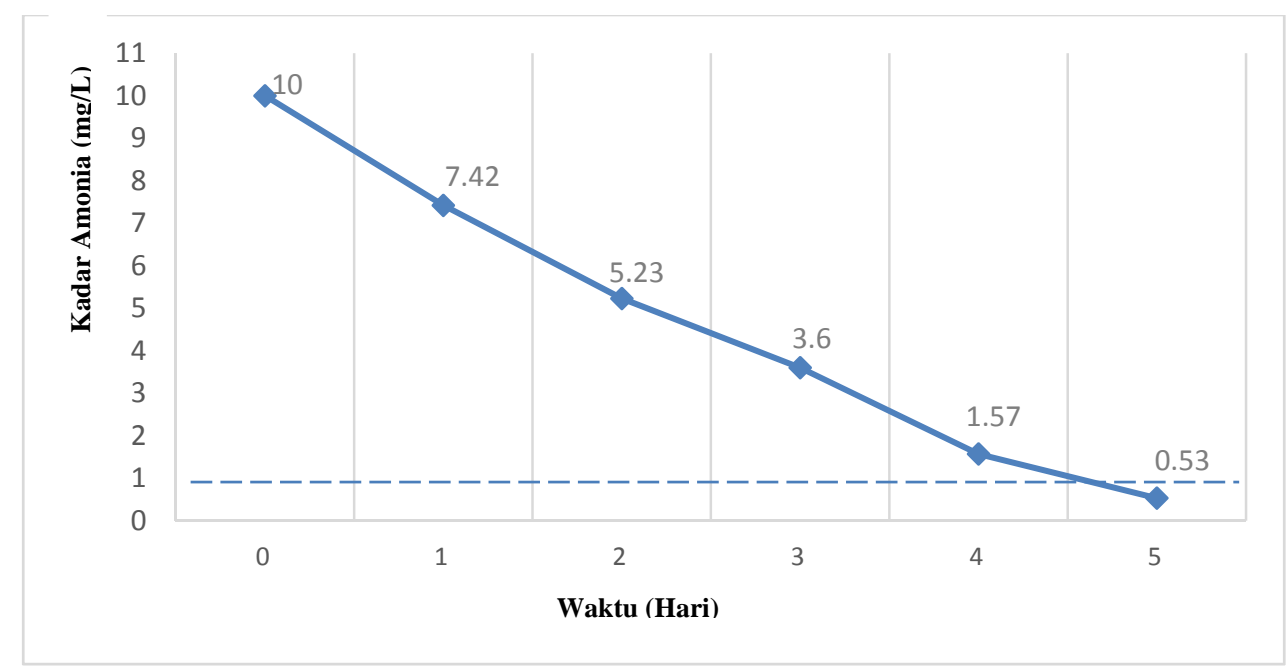

Gambar 3.

Penurunan Kadar Amonia Dengan Aplikasi Lumpur Aktif S1 Selama 5 Hari Pengolahan Dibandingkan Dengan Baku Mutu Air Limbah Rumah Sakit.

Keterangan :

- - - - = Baku Mutu Amonia Pada Air Limbah

Rumah Sakit Berdasarkan Peraturan

Gubernur Bali No. 16 Tahun 2016.

\subsubsection{Efektivitas Sistem Biofilter Anoksik- Oksik Terhadap Aplikasi Lumpur Aktif S2 \\ Dari Gambar 4 terlihat bahwa sistem} biofilter anoksik-oksik dengan aplikasi lumpur aktif S2 belum mampu menurunkan kadar amonia air limbah dibawah baku mutu 
yang ditetapkan yaitu $1 \mathrm{mg} / \mathrm{L}$. Kadar amonia pada aplikasi lumpur aktif S2 masih melebihi baku mutu air limbah rumah sakit kemungkinan disebabkan dari jumlah mikroorganisme dalam lumpur aktif belum mampu secara maksimal menguraikan amonia dalam air limbah. Dalam lumpur aktif S2 jumlah mikroorganisme (yang diukur dengan nilai MLVSS) masih rendah dibandingkan lumpur aktif yang lainya.

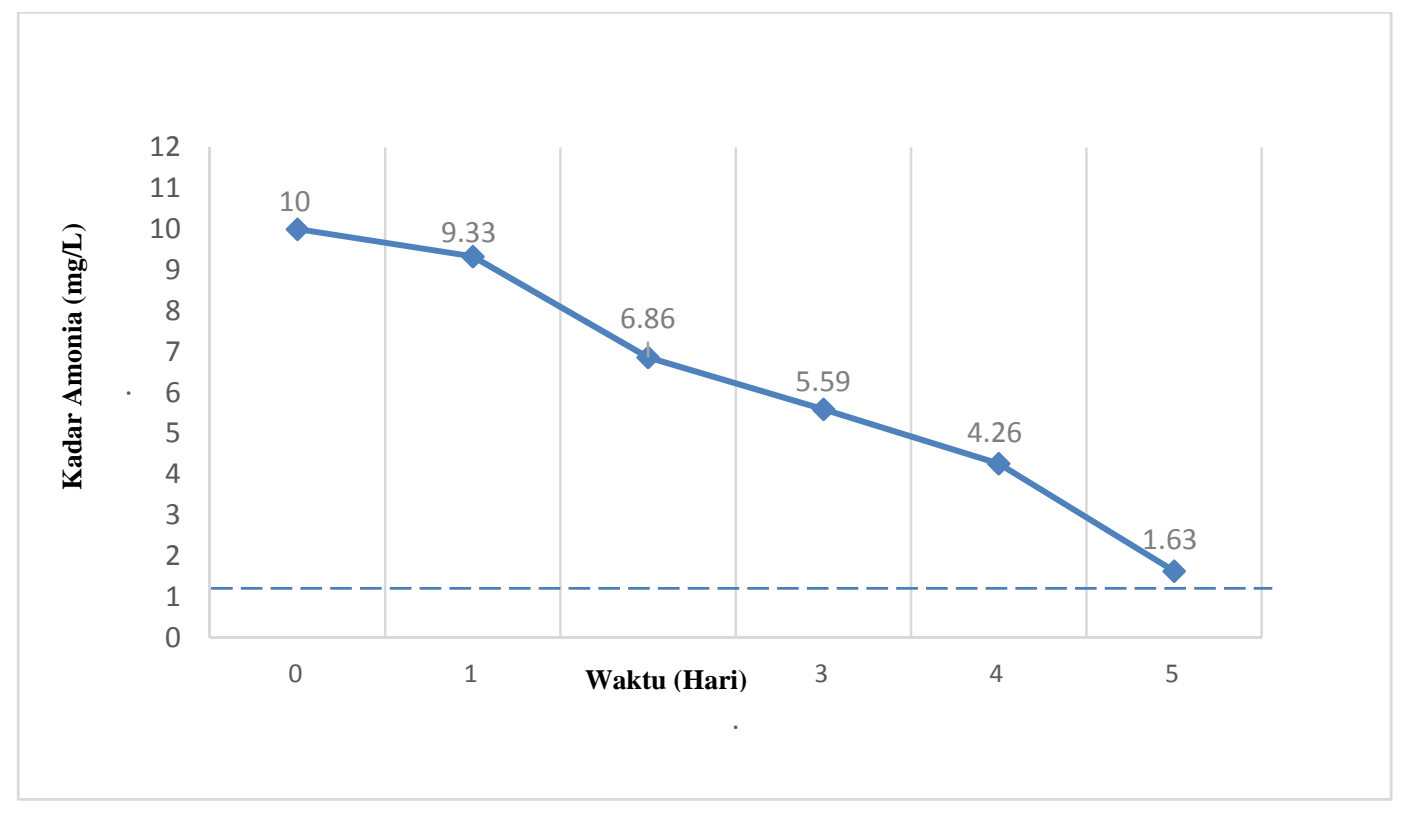

Gambar 4.

Penurunan Kadar Amonia Dengan Aplikasi Lumpur Aktif S1 Selama 5 Hari Pengolahn Yang Dibandingkan Dengan Baku Mutu Air Limbah Rumah Sakit

Untuk tingkat efektivitas sistem biofilter anoksik-oksik dengan aplikasi lumpur aktif S2, berdasarkan Tabel 1 diketahui bahwa efektivitas tahapan proses pengolahan air limbah dengan aplikasi lumpur aktif S2 menunjukkan persentase penurunan kadar amonia sebesar 83,70\%. Dari aspek efektivitas baku mutu menunjukkan aplikasi lumpur aktif S2 yang diberikan selama pengolahan selang waktu lima hari belum mampu melewati persentase efektivitas baku mutu yang ditentukan yaitu sebesar 90\% (Tabel 1). Berdasarkan kedua aspek efektivitas tersebut dapat disimpulkan bahwa sistem biofilter anoksik-oksik dengan aplikasi lumpur aktif S2 belum efektif digunakan untuk menurunkan kadar amonia air limbah.

\subsubsection{Efektivitas Sistem Biofilter Anoksik- Oksik Terhadap Aplikasi Lumpur Aktif S3}

Pada Gambar 5 terlihat bahwa sistem biofilter anoksik-oksik dengan aplikasi lumpur aktif S3 mampu menurunkan kadar amonia air limbah dibawah baku mutu yang ditetapkan yaitu $1 \mathrm{mg} / \mathrm{L}$. Selama selang waktu lima hari aplikasi lumpur aktif S3 menyebabkan terjadi penurunan kadar amonia dari $10 \mathrm{mg} / \mathrm{L}$ menjadi 0,86 mg/L. 


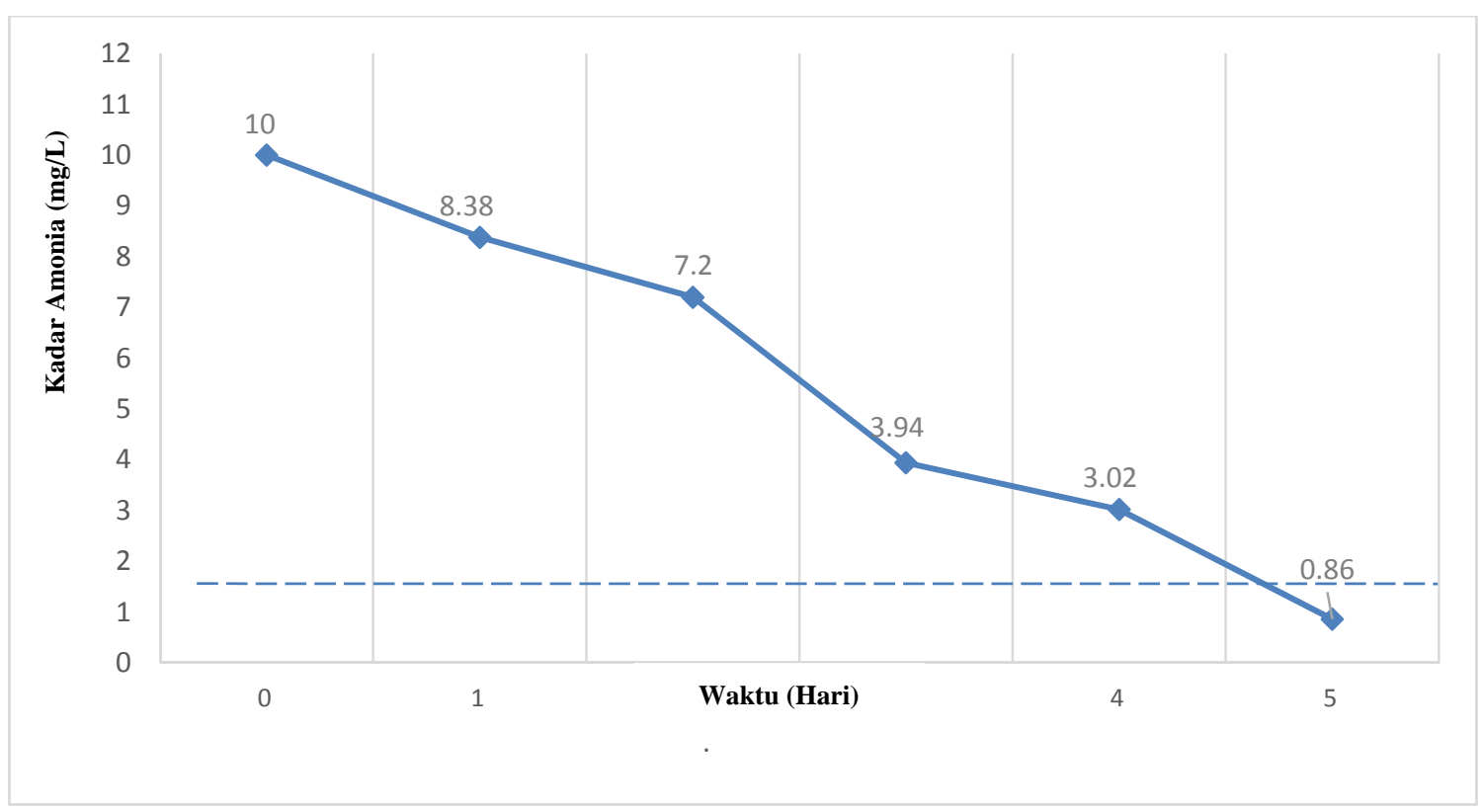

Gambar 5.

Penurunan Kadar Amonia Dengan Aplikasi Lumpur Aktif S2

Selama 5 Hari Pengolahan Yang Dibandingkan Dengan Baku Mutu Air Limbah Rumah Sakit.

Berdasarkan Tabel 1 diketahui bahwa tahapan proses pengolahan air limbah dengan aplikasi lumpur aktif S3 menunjukkan persentase penurunan kadar amonia sebesar 91,40\% selama lima hari pengolahan. Aspek efektivitas baku mutu menunjukkan selama lima hari pengolahan aplikasi lumpur aktif S3 mampu menurunkan kadar amonia air limbah melewati persentase efektivitas baku mutu yang ditentukan yaitu sebesar 90\% (Tabel 2). Merujuk pada kedua aspek efektivitas dapat disimpulkan bahwa sistem biofilter anoksikoksik dengan aplikasi lumpur aktif S3 efektif digunakan untuk menurunkan kadar amonia air limbah.

\subsubsection{Efektivitas Sistem Biofilter Anoksik- Oksik Terhadap Kontrol (S0) \\ Pada Gambar 6 terlihat bahwa sistem} biofilter anoksik-oksik terhadap kontrol (tanpa penggunaan lumpur aktif) belum mampu menurunkan kadar amonia air limbah dibawah baku mutu yang ditetapkan yaitu $1 \mathrm{mg} / \mathrm{L}$. Selama selang waktu lima hari pengolahan air limbah tanpa aplikasi lumpur aktif hanya mampu menurunkan kadar amonia dari 10 mg/L menjadi 4,73 mg/L. Sistem Pengolahan biofilter anoksik-oksik tanpa penggunaan lumpur aktif memiliki kadar amonia akhir yang masih melebihi baku mutu, dimana kondisi tersebut disebabkan karena jumlah dan keberagaman mikroorganisme yang relative sedikit menyebabkan aktivitas mikroorganisme dalam menguraikan amonia pada air limbah masih belum maksimal 


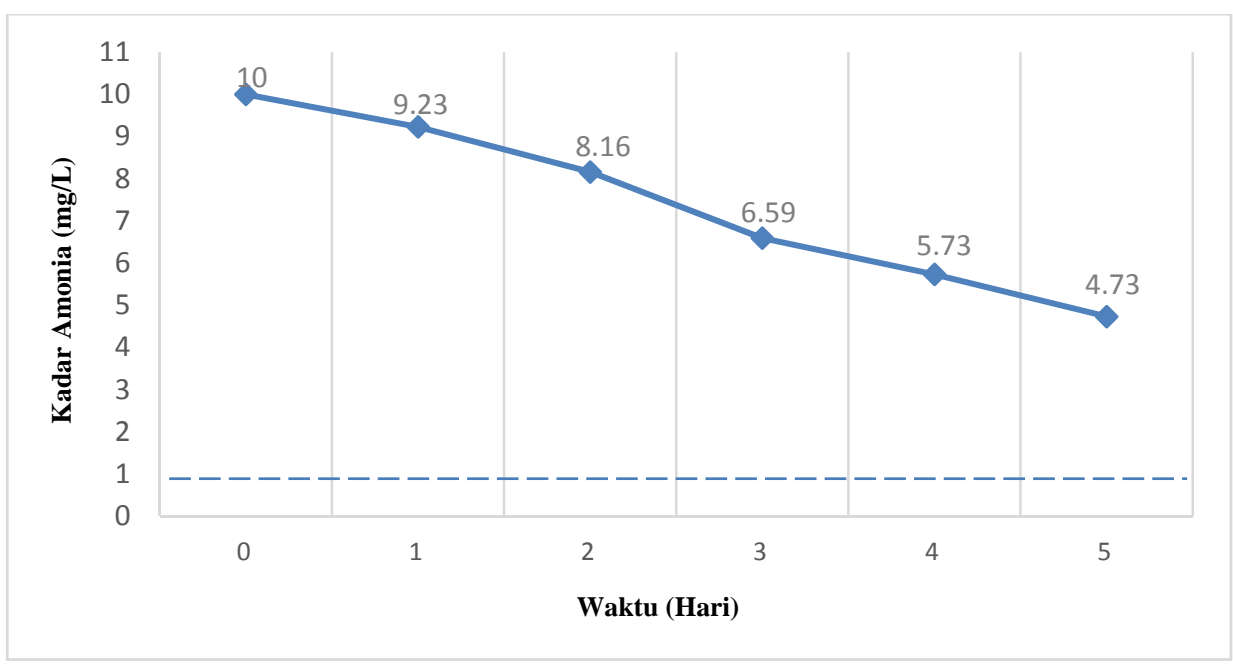

Gambar 6.

Penurunan Kadar Amonia Pada Kontrol (S0)

Selama 5 Hari Pengolahan Yang Dibandingkan Dengan Baku Mutu Air Limbah Rumah Sakit.

Tingkat efektivitas sistem biofilter anoksik-oksik pada kontrol (S0) dalam menurunkan kadar amonia air limbah, berdasarkan tabel 1 diketahui bahwa persentase penurunan kadar amonia pada air limbahsebesar 52,70\%. Untuk aspek efektivitas baku mutu pada kontrol selama selang waktu lima hari pengolahan belum mampu melewati persentase efektivitas baku mutu yang ditentukan yaitu sebesar 90\% (Tabel 2). Jika ditinjau dari kedua aspek efektivitas dapat dinyatakan bahwa sistem biofilter anoksik-oksik pada kontrol (tnpa menggunakan lumpur aktif) belum efektif digunakan untuk menurunkan kadar amonia air limbah.

\section{SIMPULAN DAN SARAN}

\subsection{Simpulan}

1. Lumpur aktif terbaik diperoleh melalui pembibitan dari IPAL RSUD Wangaya Denpasar yang ditunjukkan dengan pertumbuhan biomassa tertinggi (nilai VSS) sebesar 2433,3 $\mathrm{mg} / \mathrm{L}$ dan penurunan amonia tertinggi mencapai kadar akhir sebesar 0,53 mg/L.
2. Perlakuan sistem biofilter anoksik-oksik dengan sumber lumpur aktif dari IPAL RSUD Wangaya Denpasar (S1) mencapai nilai efektivitas proses penurunan kadar amonia sebesar 94,70\% dalam lima hari pengolahan. Sementara perlakuan dengan sumber lumpur dari IPAL RS PTN Universitas Udayana dan IPAL RSUD Bangli mencapai nilai efektivitas proses penurunan kadar amonia berturut-turut sebesar 83,70\% dan 91,40\%. Sedangkan pada kontrol (S0) nilai efektivitas proses penurunan kadar amonia sebesar 52,70\%.

\subsection{Saran}

1. Perlu adanya penelitian lanjutan mengenai jenis-jenis mikroorganisme yang mampu berkembangbiak dengan baik pada ketiga sumber lumpur aktif yang digunakan dalam sistem biofilter anoksik-oksik.

2. Dalam proses pengolahan air limbah berskala besar dengan kandungan bahan organik dan anorganik yang tinggi perlu dilakukan kombinasi sistem pengolahan sehingga efektivitas hasil pengolahan lebih maksimal. 


\section{DAFTAR PUSTAKA}

Amoo, A.E and Babalola, O.O. 2017. Ammonia-oxidizing Microorganism : Key Player in The Promotion of Plant Growth. Faculty of Natural and Agricultural Sciences, Northwest University. South Africa.

Anderson, P., 2014, "Activated Sludge

Design, Starup, Operation, Monitoring and TroubleShooting", Ohio Water Environment Association.

Crisnaningtyas, F and Vistanty, H. 2016. Wastewater Treatment Technology Using Anaerobic-aerobic and Anaerobic-coagulation on Pharmaceutical Formulation Industry. Balai Besar Teknologi Pencegahan Pencemaran Industri. Semarang.

Hanna, B. 2018. Kajian Kualitas Air Laut dan Indeks Pencemaran Berdasarkan Parameter Fisik-kimia di Perairan Distrik Depapre Jayapura. Program Studi Ilmu Lingkungan Program Pascasarjana Universitas Diponogoro. Semarang.

Herlambang, A. 2017. Teknologi Pengolahan Limbah Tekstil Dengan Sistem Lumpur Aktif. Direktorat Teknologi Lingkungan. Jakarta.

Komala, P.S., Wenten, I.G. dan Wisjnuprapto. 2017. Bioreaktor Membran Untuk Pengolahan Zat Warna Azo Dalam Air Limbah Industri Pangan. Jurusan Teknik Lingkungan Institut Teknologi Bandung. Jawa Barat.

Mary, A.H.F. 1998. Standard Method for The Examination of Water and Wastewater, $20^{\text {th }}$ edition. Publication American Public Health Association 1015 fifteenth street. NW Washington DC.
Ningtyas, R., 2015. "Pengolahan Air Limbah dengan Proses Lumpur Aktif', Jurusan Kimia, Institut Teknologi Bandung, Indonesia.

Ni'weh, L. 2014. Biogas From Solid Waste of Tofu Production and Cow Manure Mixture : Composition Effect. Program Studi Teknik Kimia Fakultas Teknik Lambung Mangkurat. Kalimantan Barat.

Putra, T.K., Sulistyani., Raharjo, M. dan Suhartono. 2018. Efektivitas Penurunan Kadar Amoniak Dan Kadar Fosfat Di Instalansi Pengolahan Air Limbah RSUD Sunan Kalijaga Demak. Fakultas Kesehatan Masyarakat Universitas Diponegoro. Semarang.

Peraturan Gubernur Bali Nomor 8 Tahun 2016 tentang Baku Mutu Lingkungan Hidup dan Kriteria Baku Kerusakan Lingkungan Hidup. 2016. Provinsi Bali.

Said, N.I. dan Rizki, M. 2014. Penghilangan Amoniak Di Air Limbah Domestik Dengan Prosesmoving Bed Biofilm Reactor (MBBR). Pusat Teknologi Lingkungan BPPT. Jakarta.

Turista, D.D.R. 2017. Biodegradasi Limbah Cair Organik Menggunakan Konsorsium Bakteri. Stikes Utama Abdi Huseda Tulungagung. Jawa Timur.

Undang-Undang Republik Indonesia (UU RI) No. 32 Tahun 2009 Perlindungan Dan Penglolaan Lingkungan Hidup. 2009. Jakarta, Indonesia: Lembaran Negara Republik Indonesia Tahun 2009 Nomor 140.

Widiyanto T. 2016. Kajian Suksesi Dan Distribusi Mikrob Dekomposer Serta Agen Bioremediasi Senyawa 
Metabolit Toksik Pada Perairan. J. Biol. Indones. 68 : 80-36.

Zanora, R. 2015. Perancangan Alat Ukur TDS (Total Dissolved Solid) Air Dengan Sensor Konduktivitas Secara Real Time. Program Pascasarjana Fakultas Matematika Dan Ilmu Pengetahuan Alam Universitas Andalas. Sumatera Barat. 